\title{
铛 PREFACE TO THE REPRINT EDITION
}

During the eighteen years since this book was first published, Coleridge scholarship has passed through what may arguably be called a golden agein which the study of Coleridge's religious thought has shared significantly. I suggested some years ago that we are in the third major period of Coleridge scholarship in this century: early in the twentieth century was the age of Coleridge the poet, and little serious attention was given to other dimensions of his work; then came "the age of Coleridge the critic and literary theorist," led by I. A. Richards and others; we are now in the age of "Coleridge the thinker"-and in recent years we have come to see what the nineteenth century never forgot, that, as Paul Magnuson has suggested, when Coleridge thought most deeply he thought about religion. ${ }^{1}$

There have been those, to be sure, who have either denied or minimized the role of religion in Coleridge's thought. Much of the current orthodoxy of Romantic studies involves, unfortunately, a "desupernaturalizing" of religious values in Romantic writing, as secularist critics read back into Romantic writers their own modern skepticism. Thus Wordsworth becomes for many an essentally non-religious poet, and the clear and strong religious dimensions of The Prelude-in the 1805 as well as the $185^{\circ}$ versions-become simply an annoying irrelevance. ${ }^{2}$ Thus Blake's profoundly biblical and Christian humanism is attenuated to the merest secularism, in which religious imagery takes on purely immanent meaning, while Shelley's religious searching is reduced to philosophical speculation. With Coleridge, the boldness of whose theological speculation is paralleled by the essential orthodoxy of his doctrinal belief, the secularizers have had a more difficult time. But the attempt is all too often made, and even as distinguished a scholar as Professor Abrams refers to Coleridge's "lifetime's struggle to save what seemed to him the irreducible minimum of the Christian creed within an essentially secular metaphysical system."3 For all this, however, Coleridgeans have increasingly come to recognize the centrality of religious concerns to Coleridge's thought, whether he is thinking

1 Review of Coleridge's Variety: Bicentenary Studies, ed. John Beer (Pittsburgh: University of Pittsburgh Press, 1975), in The Wordsworth Circle, 7 (1976), 239; for Magnuson, see 163.

2 For a brilliant refutation of the secularist approach to Wordsworth, see Anya Taylor, "Religious Readings of the Immortality Ode," Studies in English Literature, 26 (1986), 633654. Taylor concludes that Wordsworth's "arguments for transcendence indicate that traditional Christian hopes were not dead" and that Romanticism was able to "move through and beyond skepticism and to come to terms all over again with the nature of human beings and the reasons we cherish them" (652).

3 M. H. Abrams, Natural Supernaturalism: Tradition and Revolution in Romantic Literature (New York: Norton, 1971), p. 67. 
about literature, philosophy, or political life. Religion is, quite simply, at the heart of his intellectual endeavor.

The approaches to Coleridge's religious thought have been, of course, many and varied. ${ }^{4}$ One of the most provocative and influential Coleridgeans has been Thomas McFarland, whose Coleridge and the Pantheist Tradition not only affirmed but established definitively the syncretistic cast of Coleridge's mind, tracing the influence of Plato and Neo-Platonism, the Cambridge Platonists, Boehme, the German idealists, and others on Coleridge's philosophical and religious development. ${ }^{5} \mathrm{McF}$ arland is only the most notable of a number of scholars who have studied the myriad influences on Coleridge's religious thought.

If the question of philosophical and religious influences on Coleridge has been much discussed, hardly less so has been the matter of Coleridge's influence on other religious thinkers. John Coulson's brilliant study, Newman and the Common Tradition, for example, convincingly relates Coleridge to Newman through a common tradition of theological language that comes to them from the seventeenth-century Caroline divines. ${ }^{6}$ Stephen Prickett's Romanticism and Religion, building on the foundation laid by Coulson, goes on to trace the pervasive influence of Coleridge (and Wordsworth) throughout the Victorian period, on such disparate figures as John Keble, F. D. Maurice, Matthew Arnold, and fantasy-writer George McDonald. ${ }^{7}$

Much of Coleridge's influence on the Victorian period was due, at least in part, to his introduction into England of the German "higher criticism" of the Bible, Coleridge's views on which I trace in Chapter III of the present work. Three books in particular have been outstanding in their treatment of Coleridge and sacred scripture. Elinor S. Shaffer, in "Kubla Khan" and "The Fall of Jerusalem," is singularly helpful in showing the influence on Coleridge of such German biblical scholars as Reimarus, Lessing, Herder, and Eichorn. ${ }^{8}$ Jean-Pierre Mileur, in Vision and Revision, places the study

4 Two careful surveys of scholarship on Coleridge's religious thought have been of great service to Coleridgeans. Philip C. Rule, s.J., "Coleridge's Reputation as a Religious Thinker: 1816-1972," Harvard Theological Review, 67 (1974), 289-320, offers not only a history but an evaluation of the varying views on Coleridge during this period. More recently, Max F. Schulz, in the latest edition of Frank Jordan's splendid bibliography of Romantic criticism, brings his survey down to about 1982 in the section "On Religion and Theology" of his bibliographical essay, "Samuel Taylor Coleridge"; The English Romantic Poets: A Review of Research and Criticism, 4th ed. (New York: Modern Language Association, 1985), pp. 454-463.

5 Coleridge and the Pantheist Tradition (Oxford: Clarendon Press, I969).

6 Newman and the Common Tradition: $A$ Study in the Language of Church and Society (Oxford: Clarendon Press, 1970), esp. pp. 1-37.

7 Romanticism and Religion: The Tradition of Coleridge and Wordsworth in the Victorian Church (Cambridge: Cambridge University Press, 1976).

8 "Kubla Khan" and "The Fall of Jerusalem": The Mythological School in Biblical Criticism and Secular Literature, 1770-1880 (Cambridge: Cambridge University Press, 1975).

xii 
of the Bible at the center of Coleridge's interpretive work. ${ }^{9}$ Coleridge insists, Mileur says, on "the unity of temporal history with the movement of God's spirit in the world" and thus on "the ongoing immanence of the Bible in the culture whose origin it marks" (p. 94). Even more recently, Anthony John Harding's remarkable book Coleridge and the Inspired Word studies the crucial role of inspiration, both biblical and poetic, in Coleridge's religious thought. ${ }^{10}$ At the same time, Harding traces lucidly and persuasively the origins of Coleridge's views on inspiration, as well as his influence on such Victorian writers as John Sterling, Julius Hare, and F. D. Maurice, and-through James Marsh and his American edition of Aids to Reflection-on Ralph Waldo Emerson.

One of the elements on which I am most insistent in Coleridge and Christian Doctrine-especially in Chapters I and V, but elsewhere as well-is the paramount importance of the will in Coleridge's approach to religious doctrine. More recently, this aspect of Coleridge's thought has been masterfully explored, primarily from a philosophical perspective, by Laurence S. Lockridge in Coleridge the Moralist. ${ }^{11}$ He probes searchingly the ideas of freedom and alienation, duty, conscience, and love, and relates Coleridge convincingly to the tradition of British moral philosophy. Anthony Harding's Coleridge and the Idea of Love has also shed considerable light on the importance of love in Coleridge, in both its philosophical and its theological dimensions. ${ }^{12} \mathrm{My}$ own forthcoming book, Coleridge and the Power of Love, will bring yet another perspective to the ongoing reflection on the centrality of will and love in Coleridge's religious thought.

One of the most heavily trafficked areas of inquiry in recent years has been that of religious language in Coleridge. Some of this inquiry has been in the larger context of Coleridge's language theory, whether in the skeptical vein of Jerome Christensen's dazzling book Coleridge's Blessed Machine of Language, ${ }^{13}$ or in the more positive view of Timothy Corrigan's very fine Coleridge, Language and Criticism, which shows persuasively the deep interrelationships between Coleridge's theological language and the language of his literary criticism and theory. ${ }^{14}$ Other studies have considered more directly and specifically Coleridge's religious use of language.

9 Vision and Revision: Coleridge's Art of Immanence (Berkeley: University of California Press, 1982).

10 Coleridge and the Inspired Word (Kingston: McGill-Queen's University Press, 1985).

11 Coleridge the Moralist (Ithaca: Cornell University Press, 1977).

12 Coleridge and the Idea of Love: Aspects of Relationship in Coleridge's Thought and Writing (Cambridge: Cambridge University Press, 1974).

13 Coleridge's Blessed Machine of Language (Ithaca: Cornell University Press, 1981); see esp. pp. 23-25.

14 Coleridge, Language and Criticism (Athens: University of Georgia Press, 1982); see esp. Chapter V. 
One of the most influential of these is John Coulson's Newman and the Common Tradition, already mentioned, which discusses Coleridge's "fiduciary" use of language. In Coulson's view, "Coleridge perpetuates the older, alternative tradition [to the more skeptical tradition stemming from Descartes] - that a language is a living organism whose function is to reconcile the past and present experiences of a community. For him the primary response to language is not analytic, but fiduciary. In religion, as in poetry, we are required to make a complex act of inference and assent, and we begin by taking on trust expressions which are usually in analogical, metaphorical, or symbolic form, and by acting out the claims they make" (p. 4).

One very special use of religious language takes the form of symboladumbrated in Chapter II of this book-and two recent works have focused on the religious dimensions of Coleridge's use of symbol. The first is my own book The Symbolic Imagination, which grounds Coleridge's use of symbolic language in his idea of "consubstantiality," which is in turn rooted in Coleridge's profoundly sacramental view of reality and of artistic creation. ${ }^{15}$ In The Idea of the Symbol, M. Jadwiga Swiatecka, o.P. goes on to trace the parallels between Coleridge's religious conception of symbol and that of his contemporaries (especially Carlyle), and the relationship of his views to those of such Victorians as Newman, Dean Inge, George Tyrrell, and George MacDonald. ${ }^{16}$

There is one very recent work that deserves a place of its own: Anya Taylor's sensitive and moving book, Coleridge's Defense of the Human. ${ }^{17}$ Even as she focuses on Coleridge's idea of "humanness," which he affirms in the face of the dehumanizing elements of the society around him, she finds that humanness deeply bound up with God. "Coleridge's remedies for dehumanization," she writes, "are increasingly religious. As he observes the brutalizing social and political forces and the bankruptcy of mere enlightened benevolence, he calls for spirit, soul, will, reason, and supernatural revelation to lift men above beasts" (pp. 6-7). It is refreshing, in these dark Derridean times, to hear an author affirm that her book "seeks to reconstruct, not deconstruct. Rather than finding Coleridge's view persistently undermined by its opposite, it seeks to show, on the contrary, that even where Coleridge seems to be wandering in marginal by-ways, he is still seeking a direct way to the truth he knows is there. For he is not as doubting as we are, or as suspicious of the recreations of language. ... Despite

15 The Symbolic Imagination: Coleridge and the Romantic Tradition (Princeton: Princeton University Press, 1977).

16 The Idea of the Symbol: Some Nineteenth-Century Comparisons with Coleridge (Cambridge: Cambridge University Press, 1980 ).

17 Coleridge's Defense of the Human (Columbus: Ohio State University Press, 1986). xiv 
his sufferings, and maybe because of them, he still believes there is a good God, who gives coherence to the world and to our observation of it" (p. 8). This book, to my mind, breathes the spirit of Coleridge.

Most of the work on religious dimensions of Coleridge's thought has been done, not surprisingly, by literary critics. Recently, however, theologians as well have begun to study Coleridge seriously. Richard R. Niebuhr of the Harvard Divinity School, for example, has taught for a number of years a popular course on Kant, Coleridge, and Schleiermacher. Theologian Stephen Happel recently published a study in three volumes on Coleridge's Religious Imagination, which should help further the dialogue on Coleridge between critics and theologians. ${ }^{18} \mathrm{~A}$ perceptive and ground-breaking essay by James S. Cutsinger, on "Coleridgean Polarity and Theological Vision," even goes so far as to call upon his fellow theologians to turn to Coleridge, especially his ideas of polarity, as a means of transforming their way of viewing theological realities. ${ }^{19}$ "Because he challenges surface," Cutsinger writes, "and because he offers, in return, a method of seeing into unity, Samuel Taylor Coleridge may very well prove a key to a renewed theology's search for the vision and knowledge of God" (p. I08).

I have suggested elsewhere still another reason for the potential value of Coleridge for the theologian: "For some contemporary theologians, the work of theology is not merely, or primarily, the translation of the language of scripture into the abstractions of a scientific discourse, but a process of discovery in which religious experience is gradually unfolded; and since the object of the experience is a transcendent God, there is truly no end to the unfolding." ${ }^{20}$ The Coleridgean imagination, as the faculty that both creates and perceives symbols-which are organic and therefore capable of growth, emotive as well as intellectual, and open to intimations of the transcendent-can be a place of deep encounter between man and God.

Even such a modest survey as this would not be complete without a word of tribute to Kathleen Coburn, whose editorship of the Collected Coleridge has immeasurably enriched every corner of the Coleridge vineyard. Most of the volumes published to date have appeared since 1969 , and they have given us even better tools for the study of Coleridge and religion. Still more that are especially relevant for this work are on the near horizon: John Beer's edition of Aids to Reflection; the third volume of the Margi-

18 Coleridge's Religious Imagination, Salzburg Studies in English Literature (Salzburg: Institut für Anglistik und Americanistik, 1983), 3 vols.

19 "Coleridgean Polarity and Theological Vision," Harvard Theological Review, 76 (1983), 91-108.

20 "Theological Implications of Coleridge's Theory of Imagination," Studies in the Literary Imagination, 19, No. 2 (Fall 1986), 23-33; see 32. 
nalia, a continuing monument to the great work of the late George Whalley; Thomas McFarland's edition of the long-awaited Opus Maximum; and the fourth volume of the Notebooks, which will include a rich trove of theological materials. Clearly, the work goes on.

But let my final nod be to the late Basil Willey. One of the warmest and most personal books on Coleridge in recent years has been what Willey calls his "intellectual and spiritual biography" of Coleridge. ${ }^{21}$ Willey expresses eloquently what many Coleridgeans believe about STC: "The quest for religious truth and the establishment of religious faith formed the master-current of his life, to which all his other myriad interests were but tributary rills. ... One cannot understand Coleridge, or see him in true proportion, unless one has meditated with him, and tried to follow the line of his thought, on those truths to whose vindication he devoted the central energy of his life" (p. I I).

I am pleased indeed that my work of almost twenty years ago is still found useful. One of the pleasures of being a professional Coleridgean is to be part of a community of scholars who strive to work in the spirit of Coleridge, who find in him a model-if not for every aspect of their lives, yet surely for tenacity of spirit and the active life of the mind. To be part of such a community is a privilege and a joy.

University of Missouri-Columbia

J. R. B.

Feast of the Ascension

May 1987

21 Samuel Taylor Coleridge (New York: Norton, 1972). 